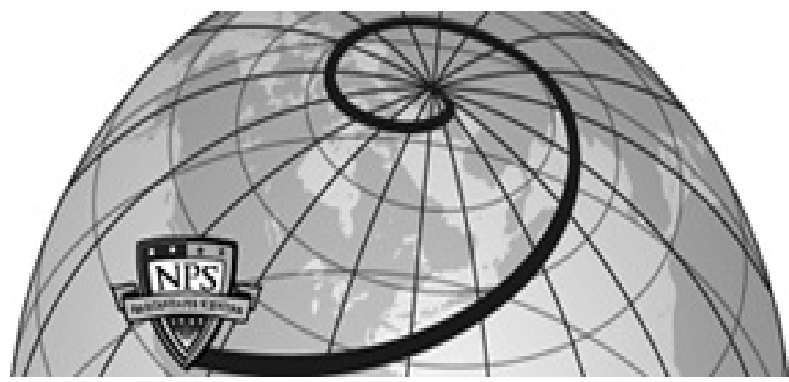

Calhoun: The NPS Institutional Archive DSpace Repository

The political economy of aid and governance in Cambodia

\title{
Ear, Sophal
}

Routledge

Asian Journal of Political Science, v.15, no.1 April 2007, pp. 68-96

https://hdl.handle.net/10945/43170

This publication is a work of the U.S. Government as defined in Title 17, United States Code, Section 101. Copyright protection is not available for this work in the United States.

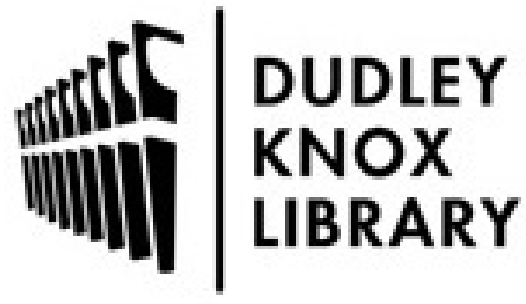

http://www.nps.edu/library
Calhoun is the Naval Postgraduate School's public access digital repository for research materials and institutional publications created by the NPS community. Calhoun is named for Professor of Mathematics Guy K. Calhoun, NPS's first appointed -- and published -- scholarly author.

Dudley Knox Library / Naval Postgraduate School 411 Dyer Road / 1 University Circle Monterey, California USA 93943 


\section{The Political Economy of Aid and Governance in Cambodia}

\section{Sophal Ear}

The impact of massive aid on development and governance has been studied for a decade with mixed results. Using the results of an elite survey on aid and quality of governance based on Kaufmann et al.'s six dimensions (voice and accountability, political stability, government effectiveness, regulatory quality, rule of law, and control of corruption), this article offers a case-study of Cambodia. The country's challenges in light of high aid dependence and 'Dutch disease' in the aid sector are elaborated, and disappointing human development outcomes are examined. Despite more than five billion dollars in aid, infant and child mortality and inequality have worsened. Key informants are overwhelmingly in agreement that, save for political stability, aid has not had a positive impact on governance in Cambodia. The failure on control of corruption shows how hard it is for donors to be tough on a country with extreme poverty. On the basis of what has been accomplished to date, however, aid seems unlikely to be able to deliver large improvements in governance and in many ways may even contribute to its further deterioration.

Keywords: Cambodia; Governance; Foreign Aid; Corruption; Democracy; Stability

\section{Introduction}

What are the consequences for governance in Cambodia of the massive amounts of aid it has received since 1993? Post-conflict Cambodia had little choice on whether or not to engage donors or, in a wider sense, about how to relate to the overall global political economy. The country was a 'pariah' state for the duration of the 1980s in the aftermath of the Khmer Rouge period and the Vietnamese invasion of Cambodia,

\footnotetext{
Sophal Ear, PhD, is currently a Post-Doctoral Fellow in the Department of Public Administration at the Maxwell School of Citizenship and Public Affairs, Syracuse University, USA. Beginning in June, he will be an Assistant Professor in the Department of National Security Affairs at the Naval Postgraduate School in Monterey, California. Correspondence to: Sophal Ear, Department of National Security Affairs, Naval Postgraduate School, 1411 Cunningham Rd., Monterey, CA 93943, USA. Tel.: +1 510996 6911; Fax: +1 775878 0116; Email: sophal@alumni.princeton.edu
} 
and intensely sought to establish normal international relations and acceptance. Following the Cold War, the Paris Peace Agreement signed on 23 October 1991 signalled the cessation of open warfare, though not the end of conflict itself for Cambodia. Following the country's two billion dollars UN-organised elections in 1993, Cambodia received five billion dollars in Official Development Assistance (ODA), ${ }^{1}$ turning it into one of the most aid-dependent countries in the world, with half of its national budget funded from ODA. However, the lack of choice does not mean the lack of consequences.

In 1996, Peter Boone of the London School of Economics raised the danger that the provision of massive amounts of ODA might be counterproductive for development. Subsequent to his study, there have been dozens of scholarly exchanges ${ }^{2}$ using cross-national data (Burnside and Dollar, 1997; Easterly, 1997; Hansen and Tarp, 1999) on the questions Boone's assertion raises, including whether massive amounts of ODA might have negative consequences for governance. Indeed, aid dependence ${ }^{3}$ has been asserted to be empirically linked with the worsening quality of governance (Knack, 2001). These analyses are contradictory in some respects and the general conclusion is that the effects of ODA on governance vary from country to country and need to be examined at the case-study level. This article offers a casestudy of Cambodia.

Using Kaufmann et al.'s (1999) six dimensions of governance (voice and accountability, political stability, government effectiveness, regulatory quality, rule of law, and control of corruption), this article asks two questions: (1) what is the relationship between the Kaufmann et al. (2006) scores and the very large amounts of ODA Cambodia has received; and (2) can ODA be said to cause the rankings and/or their changes?

To answer these questions, 43 key informants in Cambodia rated donor success across Kaufmann et al.'s six dimensions of governance. These informants were selected from various sectors, but all were involved in an intense way with ODA flows and the performance of the Cambodian government. All of them had a minimum of three years' experience in Cambodia and their mean level of in-country experience was eight years, with a median of seven years. These informants do not 'represent' even the population from which they were derived, but they do represent a very deep set of experiences that can help explain the core dynamics of aid, development, and governance in Cambodia.

The informants are heavily involved in Cambodian development ( $84 \%$ are employed in donor agencies or non-governmental organisations) and have a great deal of professional expertise ( $89 \%$ are managers or advisers). Collectively, they suggest that the donor community affected change in the following dimensions of governance (percent represents donor success rated as medium to very high): political stability (67\%); voice and accountability (47\%); government effectiveness $(30 \%)$; regulatory quality (29\%); rule of law (12\%); and control of corruption (7\%). These key informants overwhelmingly agree that, except for political stability, foreign aid has not had a positive impact on governance in Cambodia. Indeed, as will be discussed in 
greater detail for control of corruption, some informants were highly critical of the donors. The failure on corruption shows how hard it is for donors to be tough on a country that is genuinely aid-dependent for the survival of much of the population. ${ }^{4}$

In explaining governance outcomes, the importance of domestic political will and political leadership cannot be overstated as key factors responsible for Cambodia's quality of governance. This is a subject explored in greater detail in Ear (2005: 17), precisely 'how well words have turned into action when it comes to governance in the context of Cambodia's economy'. It reviews a decade of achievements and failures of governance in Cambodia, provides a framework through which to evaluate the likelihood of success, and discusses trends in donor and government strategies - touching upon the Royal Government of Cambodia's (RGC) 'Rectangular Strategy for Growth, Employment, Equity and Efficiency' (RGC, 2004). It proposes instead a 'Rectangular Reality' in which political will is juxtaposed against policy environment and four quadrants emerge distinguishing areas in which the RGC has political will (as evaluated by outcomes, results, and practices) or lacks it, and has a policy or not. Political will for exchange rate stability, inflation control, a market economy, and World Trade Organisation membership exists, as do policies. However, support and policy for anti-corruption that meets the standards of the United Nations Convention against Corruption is absent, as is separation of powers - particularly of the Judiciary from the Executive as required by the Constitution. Citing the absence of credible signs of domestic leadership for reform, the World Bank abandoned its legal and judicial reform activities in Cambodia in 2004. Lack of political will and poor leadership are paramount factors responsible for the poor governance of Cambodia. However, this article covers the role and performance of donors in effecting change in Cambodia's governance. Given the existing low level of political will and poor leadership, what is possible at the margins and what has been achieved? Donors should and need to become aware of their own impact on the governance outcomes observed in Cambodia. As such, what impact on governance have donors had? What works, what doesn't, and - possibly - why?

This article is divided into six sections. Following this introduction, the next section provides a literature review on how aid can influence development and governance. The third section discusses the political economy context of the last decade for aid to Cambodia and analyses the challenges faced in light of high aid dependence and 'Dutch disease' in the aid sector. The fourth section focuses on the Aid and Governance Survey that was undertaken in April-May 2005. The fifth section examines the change and continuity in donor roles with guidance from the survey findings. Donors have at times pushed for voice and accountability publicly, while privately they have sought political stability. The final section summarises the major findings of this article.

\section{Literature Review on Aid, Development and Governance}

Foreign aid has long been justified as essential for development under incomplete market conditions in which investment is missing (hence the need for aid). ${ }^{5}$ Boone 
(1996) was the first to consider, empirically, a country's political system in determining aid effectiveness. In this sense, he was a pioneer in analysing governance and aid. ${ }^{6}$ He found that aid does not significantly increase investment, nor benefit the poor as measured by improvements in human development indicators, but it does increase the size of government. According to Boone (1996: 322), 'poverty is not caused by capital shortage, and it is not optimal for politicians to adjust distortionary policies when they receive aid flows'. The impact of aid does not vary according to whether recipient governments are liberal democratic or highly repressive. But liberal political regimes and democracies, ceteris paribus, have on average $30 \%$ lower infant mortality than the least free regimes.

His study is credited with having single-handedly motivated World Bank economists Craig Burnside and David Dollar to perform their own analysis in an attempt to rescue aid from (political) irrelevance. ${ }^{7}$ Burnside and Dollar (1997) substituted Boone's political system proxy with a quality of policy proxy and found that money matters in a good policy environment. Under weak economic management in developing countries there is no relationship between aid and change in infant mortality, but in countries where economic management is stronger, there is a favourable relationship.

Hansen and Tarp (1999) argued that the Burnside and Dollar findings were the result of diminishing returns to aid. While analysing the same set of countries as Burnside and Dollar and using the same basic model specification, Hansen and Tarp conclude, in contrast to Burnside and Dollar, that aid does have a positive impact on growth even in countries with a poor policy environment. They surveyed the results of 29 papers published between 1968 and 1998, re-estimated the Burnside and Dollar model, and conclude that 'using past performance as an indicator of future performance is especially dubious in this environment, given the existing limited understanding of the interplay between aid, macroeconomic policy, and political economy variables' (1999: 17-18). ${ }^{8}$ In a veiled reference to the World Bank's 1998 study Assessing Aid: What Works, What Doesn't, and Why, they write, 'In sum, the unresolved issue in assessing aid effectiveness is not whether aid works, but how and whether we can make the different kinds of aid instruments at hand work better in varying country circumstances' (1999: 18).

Beyond questions of aid effectiveness, there emerged concerns of aid dependence being linked with the worsening quality of governance. By 1999, Bräutigam and Botchwey argued that the pre-existing quality of governance determined the extent to which aid undermined institutions. Bräutigam (2000) followed up with a qualitative study of aid dependence and governance.

Knack (2001), whose findings are re-examined in Ear (2006, 2007), offers a significant literature review of how aid dependence can worsen governance defined more specifically as corruption, bureaucratic quality, and rule of law. ${ }^{9}$ His own crosssectional analysis finds that a negative relationship exists between aid dependence and quality of governance. According to Knack, aid dependence hurts quality of governance by weakening institutional capacity, siphoning off scarce talent from 
the bureaucracy, weakening accountability, encouraging rent seeking and corruption, fomenting conflict over control of aid funds, and alleviating pressures to reform inefficient policies and institutions.

Knack's (2001) findings pose a serious problem for international development. For example, while donors have been reticent to expose themselves to criticism, there was a glimmer of introspection in the case of Cambodia. The World Bank's 2004 annual donor pledging session which it co-chairs with the RGC, known as the Consultative Group Meeting, saw the Bank's background document, Cambodia at the Crossroads, contain a chapter entitled 'Improving Aid Effectiveness'. Although the chapter offers no specifics, save for 'numerous examples', the World Bank (2004a: 108) admits that:

There is much that donors can and should do to make their assistance to Cambodia more effective. There are numerous examples of how donors have behaved, individually and collectively, which result in inefficient and ineffective aid; or which even make things worse by contributing to (or exacerbating) a culture of corruption and patronage in the use of public resources. Poorly managed aid can inadvertently impede the evolution of a coherent Government vision of long-term development; or undermine the capacity of institutions of the state and delegitimize civil society organizations.

But even if aid dependence hurts governance, as Knack found in his cross-national study, which dimensions of governance, aside from bureaucratic quality, corruption, and rule of law (dimensions he tested) are most affected and how? Beyond this, how do we not throw out the baby with the bathwater? Even if for no other reason, the drive to assess aid (and to pin the blame on poor governance) by International Financial Institutions themselves is an act of self-preservation. Worldwide aid levels have been on the decline since 1992, when they peaked. The World Bank was so moved as to appeal directly to donor countries to essentially hang in there and continue funding. Their Assessing Aid (1998) report found that the impact of aid on growth and infant mortality depends on 'sound economic management', as measured by an index of economic policies and institutional quality. ${ }^{10}$ Indeed, these policy conclusions are obliquely mentioned without specific attribution in the same chapter of Cambodia at the Crossroads. The report states, "There is an increasing body of evidence that aid effectiveness depends heavily upon the existence of a sound institutional and policy environment' (World Bank, 2004a: 122).

Since Ear $(2006,2007)$ explores and criticises the empirical work of Stephen Knack (2001) using the Kaufmann et al. data under pooled time series cross-section analysis, this article focuses on Cambodia as a case-study of the relationship between aid and governance. It follows Knack's (2001: 326) advice that 'a case-study approach should examine more closely the recent experience of high-aid countries with deteriorating institutional quality'. Cambodia, while not cited by Knack as a potential case-study, is highly aid-dependent and has experienced deteriorating institutional quality as detailed in the following sections. 


\section{Cambodia's Political Economy Context: War, Revolution, and Peace}

\section{Historical Background}

Cambodia gained independence from France on 9 November 1953 and for most of its modern history was led by His Majesty Norodom Sihanouk. Through the 1960s, Sihanouk's Sangkum Reastr Niyum or Popular Socialist Community movement embarked on agricultural cooperatives, emphasising state-owned enterprises, and launching numerous construction projects within the context of a market economy. From a long-term perspective, the Cambodia conflict can be said to have started on 13 March 1970, when a coup d'etat against Sihanouk by his Prime Minister Lon Nol and Deputy Prime Minister Sirik Matak (a cousin of Sihanouk) led to the birth of the Khmer Republic. Cambodia abandoned its neutrality and sided fully with the United States against North Vietnam.

On 17 April 1975, Phnom Penh fell to the Khmer Rouge, a communist insurgent movement, whose forces grew in strength when a deposed Sihanouk absorbed their movement into his government in exile. Cambodia adopted an agrarian Maoist economy where, over the course of less than four years, nearly two million people died. The new government, led by Pol Pot with nominal heads of state Sihanouk (in the first year) and Khieu Samphan, renamed the country Democratic Kampuchea. Currency and private property were banned.

After a year of border skirmishes with Vietnam, the latter invaded Democratic Kampuchea in December 1978, capturing Phnom Penh on 7 January 1979. Thus, the darkest chapter in Cambodia's history ended with a quarter of the population dead, but a new one began in which the country lost its sovereignty. Until 1989, 140,000 Vietnamese troops were based in Cambodia. The parties to the conflict were the Vietnamese proxy government of the People's Republic of Kampuchea (the country was renamed the State of Cambodia in 1989), the Khmer Rouge, then based on the Thai-Cambodian border, and a non-communist resistance composed of the royalist Funcinpec $^{11}$ and the Khmer People's National Liberation Front.

The period 1975-1989 took Cambodia to its nadir. The major impacts of the conflict were overwhelming. Massive loss of human resources from death, disease, and displacement (hundreds of thousands of Cambodians became refugees, many resettling in third countries). Indeed, the United Nations (1992: 26) estimated that most of the highly qualified Cambodians were living outside the country, among them Cambodia's best and brightest, systematically targeted by the Khmer Rouge as a threat to regime. By 1993, the University of Phnom Penh which had been among the best universities in Asia prior to the conflict had 'almost no books, few professors and only a handful of classrooms that were not shot to pieces as the Khmer Rouge raged into Phnom Penh [on 17 April 1975]' (Gibson, 1993).

On 23 October 1991, the parties signed in Paris the 'Agreements on the Comprehensive Political Settlement of the Cambodia Conflict' - a peace treaty to end the conflict and prepare the country for elections. The Agreements assigned to the United Nations an unprecedented role - a two billion dollar mission known as 
the United Nations Transitional Authority in Cambodia (UNTAC) would supervise the ceasefire, the end of foreign military assistance, and the withdrawal of foreign forces. UNTAC would regroup, canton, and disarm all armed forces of the Cambodian parties, and ensure a 70\% level of demobilisation. UNTAC would control and supervise the activities of the administrative structures, including the police; ensure and respect of human rights; and organise and conduct free and fair elections. ${ }^{12}$ Of course, these were lofty goals; the reality differed markedly.

\section{Setting the Economic Context in the Late 1980s and 1990s}

Two major economic factors were at play by the time UNTAC arrived. First, the loss of aid from the former Soviet Bloc countries (the Council for Mutual Economic Assistance/Comecon in particular) severely affected public sector finances, and caused macroeconomic imbalance - a budget deficit of nearly 4.6\% of GDP in 1992 (World Bank, 1994). Aid dropped 35\% from 1987 to 1988, while trade as a percentage of GDP stagnated between 1989 and 1990. Second, immediately following this period, Cambodia experienced extremely high inflation and exchange rate instability. Retail price inflation exceeded $100 \%$ for much of the early 1990 s.

In 1989, when the Vietnamese army began to leave Cambodia, aid doubled, and in 1991 it tripled. It was that year that the then United Nations Secretary-General Javier Perez de Cuellar appealed to the international community to support Cambodia's rehabilitation efforts following the signing of the Paris Peace Accords in October 1991. This resulted in pledges and other commitments totalling $\$ 880$ million at the first International Conference on the Rehabilitation of Cambodia (ICORC) in Tokyo in June 1992. New pledges of \$119 million were added in September 1993 in Paris. In 1994, the total amount of aid committed to Cambodia at the second ICORC in Tokyo again garnered over $\$ 800$ million through 1996 . $^{13}$

\section{Aid Dependence: 'Dutch disease' and Fungibility}

From 1993 to 2003, five billion dollars of ODA averaging 13\% of GDP annually was given to Cambodia. Today, foreign aid accounts for half the national budget, and while this aid is intended to help develop the country, its massive infusion has also served to distort an economy with limited absorptive capacity. Not including nongovernmental organisations (NGOs) operating in Cambodia, of which there are hundreds, the table below details the activities of 31 donors and suggests the massive extent of their interventions relative to the RGC.

While aid was desperately needed for reconstruction, it became apparent by the turn of the millennium that aid also has had unintended and undesired consequences. Two specific problems are apparent:

The scale of aid is such that it distorts the economy. In an aid-related version of 'Dutch disease', a high proportion of Cambodia's scarcest resource, educated 
Table 1 Selected Indicators of Aid Dependence in Cambodia

\begin{tabular}{lcc}
\hline Indicator & Year & Value \\
\hline Number of donors & 2003 & 31 \\
Number of donor-supported activities & 2003 & 410 \\
ODA as percentage of GNI & 2002 & $12.7 \%$ \\
ODA as percentage of imports & 2002 & $16.7 \%$ \\
Reported external assistance flows & $1996-2001$ & $\$ 2,672 \mathrm{~m}$ \\
$\ldots$ compared to total Treasury-executed expenditures & $1996-2001$ & $\$ 2,122 \mathrm{~m}$ \\
Percentage of total public spending accounted for by ODA in: & Year 2001 & $\%$ \\
Health & 2001 & $65.9 \%$ \\
Agriculture & 2001 & $67.4 \%$ \\
Transport & 2001 & $68.1 \%$ \\
Area/rural development & 2001 & $88.8 \%$ \\
\hline
\end{tabular}

Source: World Bank (2004a: 111).

people, is pulled toward employment in donor agencies and international nongovernmental organizations or attached to projects as salary-supplemented counterparts. At the same time, donors and NGOs virtually take over the funding of education, health care, social welfare, rural development etc., while government spends most of its funds on defense and security. (Godfrey et al., 2000: 123)

The 'Dutch disease' effect is particularly pernicious. Observed in the Netherlands in the 1960s when large reserves of natural gas in the North Sea were first exploited, the 'Dutch disease' refers to the inflow of foreign exchange that de-industrialised the Dutch economy. In the case of Cambodia, aid crowds out other sectors, becoming a tradable sector financed by 'revenues' in the form of aid. Donor-financed workshops and conferences abound; civil servants are often abroad on 'study tours' with their salaries supplemented.

It should be said that civil servants' salaries are barely above the poverty line of circa 45 cents per day per person making moonlighting or gravitation towards the aid sector almost a fait accompli. Yet civil service reform is not a high priority for the RGC for political economy and patronage reasons, enabling the abuse of public office for private gain. Salaries - still in the \$20-40 per month range-have increased, but have not kept up with inflation. The Soviets used to joke, 'They pretend to pay us and we pretend to work' The same can be said of civil servants in Cambodia. The second problem described by Godfrey et al. (2000) in which aid allows government not to spend on basic services, without using its moniker, is that of aid 'fungibility.' ${ }^{14}$ By 2005, the analysis remained the same. A foreign expatriate manager with a dozen years' experience with a membership organisation of local and international NGOs complained that 'In some ways, donor projects have stifled government initiative, placing foreign agencies largely in charge of the government's service provision responsibilities'. Another foreign expatriate with five years' experience in international and local NGOs added: 'In some ways NGOs can't avoid working with the government. In some ways they should.' 
What the aid variant of the 'Dutch disease' implies for Cambodia is the functional equivalent of brain drain into the aid sector from both the government and the private sector - widely acknowledged as the engine of growth in any country. This is what Knack (2001) calls the siphoning of scarce talent from the bureaucracy. State capacity is weakened when the best and brightest are neither entrepreneurs nor government policy wonks. Working for donors, they will naturally be donordriven - and while the goal of aid may be development - for bilateral aid it is more often than not the donor country's foreign policy and national interest that take precedence. ${ }^{15}$ In Cambodia, aid spent by donors on 700 international consultants in 2002 was estimated to total between $\$ 50$ and $\$ 70$ million, approximately equal to the wage bill for the country's 160,000 civil servants (ActionAid, 2005: 22). Donorfinanced consultants working in the RGC are paid upwards of 200 times what their Cambodian counterparts receive (ibid.).

Having established that aid may distort the Cambodian economy by siphoning talent from government and the private sector, it is apparent that the country's tenuous balance between aid and governance needs to be rewritten. Clearly, there is an urgent need to focus aid on improving governance. As both the Prime Minister and the Finance Minister have said on separate occasions in 2001, the RGC is 'conscious that good governance is a sine qua non condition for promoting social and economic development and sustainable social equity' (Hun, 2000; Keat, 2001). ${ }^{16}$ Deputy Prime Minister Sok An (2003) quipped, 'There is no need to plead the case of good governance. We are all converts. ${ }^{17}$ Yet, if pleading the case of good governance is to preach to the converted, actions (and political will) still speak louder than words. What progress in development outcomes has been made to date?

\section{Development Outcomes: Infant and Child Mortality, Poverty, and Inequality}

A decade of Cambodian development has proven that technical solutions often fail in the face of political reality. Notwithstanding large annual infusions of aid, what is known of development in Cambodia is this: infant and child mortality, as reported by the World Bank, have risen since 1990 despite real GDP growth of circa 7\% per year in the last decade. This and subsequent data are from the World Bank (2005b).

In 1990, 80 infants out of 1,000 died in their first year. By 2001, that number had increased to nearly 97 in 1,000. While a jump over the course of a decade may be an anomaly, what gives confidence in this trend is the continuous rise for the years in between: 1992, 1995, 1997, and 2000. Moreover, child mortality (under five) also rose steadily from 115 per 1,000 in 1990 to 120 in 1995, 135 in 2000, and finally 140 in 2001. Together, infant and child mortality rates are the highest in the region, higher than even Timor-Leste which in 2003 had an infant mortality of 87 in 1,000 and a child mortality rate of 124 in 1,000 (the equivalent of 1995 Cambodia). Moreover, illness can often be catastrophic, with high costs and low quality of care, leading families to borrow at usurious interest rates or sell their only assets - livestock and land. Kenjiro's (2005) village-level research found that illness causes more land sales than crop failure. 
For example, while floods destroy crops, they also enable fishing which produces income or provides protein. In contrast, 'given the lack of health insurance and insufficient governmental support to the health-care sector, Cambodians have to bear all their own medical costs when they become sick' and micro-credit, while available in some areas, have high interest rates and are inflexible (Kenjiro, 2005: 780).

With respect to poverty reduction from 1994 to 2004, indications were that little to no progress had been made through early 2005. This changed by late 2005 and early 2006 when World Bank (2006) announced a significant 12\% decrease in poverty over the last decade based on household consumption data collected in 2004. The World Bank recalculated the national poverty rate in 1993/1994 from 39\% (Prescott and Pradhan, 1997; World Bank, 1999) to 47\% using backward projection. Thus, instead of announcing that poverty had decreased very modestly from $39 \%$ to $35 \%$ in 1993-2004, the Bank announced that poverty had decreased from $47 \%$ to $35 \%$. In $1993 / 1994$, only $56 \%$ of Cambodian villages and only $65 \%$ of rural areas were accessible. The backward projection assumes that the remainder of the country, largely controlled by the Khmer Rouge (by then known formally as the Democratic Party of Kampuchea or DPK), was much poorer than its non-DPK counterpart. ${ }^{18}$

Moreover, sensitivity analysis reveals the lack of robustness in the World Bank (2006) findings. If the 2004 national poverty line (1,826 Riels or $\$ 0.45$ per person per day) is increased by only $10 \%$, or 183 Riels $(\$ 0.045)$, the national poverty rate jumps to $41.6 \%$ from $35 \%$. This $6.1 \%$ difference represents a $17.4 \%$ increase in poverty. Caution should thus be exercised in interpreting the gains made in reducing poverty in 1994-2004. More worrisome, inequality was found to have increased significantly. In the non-DPK parts of Cambodia that were surveyed in 1993/1994, the Gini coefficient for real per capita consumption was 0.35. This increased to 0.40 in 2004 . The Gini coefficient for all of Cambodia was 0.42 in 2004, making the country one of the most unequal in the region.

\section{Aid and Governance Elite Survey in Cambodia}

On 24 April 2005 the author launched a confidential elite survey on aid and governance in Cambodia. The online portion of the survey was open for informants for a period of 10 days. While the total usable responses totalled $43,{ }^{19}$ the survey should be understood as representing only the views of those who responded. ${ }^{20}$ The usefulness of this survey, in contrast to the Kaufmann data (on which the survey's dimensions and definitions are based), is to explore the relationship between aid and governance among development experts. While the Kaufmann data places Cambodia in the context of other countries in terms of governance performance, it says nothing about the success of donors at changing the various dimensions of governance in Cambodia. These informants were drawn from a potential group (targeted individuals and large email distribution lists on Cambodia) which probably is no larger than 200 from the number of individuals who received (or were forwarded) ${ }^{21}$ the message (a total of about 1,000) and met the criterion of three years' professional 
experience working in development in Cambodia. The survey instrument probably reached a significant number of individuals in the donor and NGO community, as well as a few in the RGC who had the requisite credentials and internet access. The response rate was about $21.5 \%$ of the relevant (informed) population of 200 , although the RGC respondents were under-represented. Informants listed themselves as working for donor agencies (43\%), international NGOs (25\%), local NGOs (16\%), RGC $^{22}(16 \%)$, many of whom were some combination thereof. ${ }^{23}$ Informants averaged eight years of development experience in Cambodia, with a median of seven years. Of these, $61 \%$ were foreign expatriates, $11 \%$ were Cambodian expatriates, and 27\% were citizens of Cambodia only. ${ }^{24}$ More informants classified themselves as advisors (52\%) than managers (37\%), followed by educational or research capacity $(6 \%)$ and other $(5 \%){ }^{25}$ Choices were not mutually exclusive permitting informants to cross-list themselves.

\section{Survey Background}

The survey posited different impacts for aid in moderate to highly indebted, aiddependent countries such as Cambodia and offered three possible hypotheses:

(a) Some believe that the country's dependence on aid makes it highly responsive to donor demands and therefore prone to reform along international lines.

(b) Others believe that high indebtedness and a high poverty rate put great pressure on donors to give even when the governance situation is disappointing. In effect this gives the government freedom to ignore donor pressures and perpetuates poor governance.

(c) Still other observers believe that the picture varies according to the dimension of governance one examines, perhaps because of unevenness in donor priorities.

The literature has identified six dimensions of governance. These are defined in Table 2.

\section{How Cambodia Ranks across Kaufmann et al.'s Six Dimensions of Governance}

Before delving into the survey results - how donors succeeded (or not) in effecting change in the six dimensions of governance outlined above-examining how Cambodia itself performed across these same dimensions of governance is useful. The most recent release of the Kaufmann et al. governance indicators, Governance Matters V, was launched on 15 September 2006, more than a year after the survey conducted for this article closed in early May 2005 (and days before Governance Matters IV was released on 9 May 2005). As such, the rankings below could not have been used by the respondents and could not have influenced them. Governance Matters $V$ provides percentile rankings for Cambodia in 1996, 1998, 2000, 2002, 2003, 2004 and 2005 across all six dimensions of governance. Cambodia's rankings 
Table 2 World Bank's Governance Indicators

Governance is defined as 'the traditions and institutions by which authority in a country is exercised'

Process by which governments are selected, monitored, and replaced
Capacity of the government to effectively formulate and implement sound policies
Respect of citizens and the state for the institutions that govern economic and social interactions among them
1) Voice and accountability: Various aspects of the political process, especially civil liberties, political rights, and independence of the media

2) Political stability: The likelihood that the government in power will be destabilized or overthrown by possibly unconstitutional and/or violent means, including terrorism
3) Government effectiveness: The quality of public service provision, the quality of the bureaucracy, the competence of civil servants, the independence of the civil service from political pressures, and the credibility of the government's commitment to its policies

4) Regulatory quality: The incidence of market-unfriendly policies such as price controls or inadequate bank supervision, as well as burdens imposed by excessive regulation in areas such as foreign trade and business development
5) Rule of law: The incidence of both violent and non-violent crime, the effectiveness and predictability of the judiciary, and the enforceability of contracts

6) Control of corruption: Corruption, conventionally defined as the exercise of public power for private gain. This ranges from the frequency of 'additional payments to get things done', to the effects of corruption on the business environment, to 'grand corruption' in the political arena or in the tendency of elites to engage in 'state capture'

Source: Adapted from Kaufmann et al. $(1999,2006)$.

for all dimensions of governance suggests a turbulent nine years. However, some trends are evident (see Figure 1).

Cross-national rankings of the six dimensions of governance place Cambodia very low, at the 31st percentile or below in 2005. The only two areas in which Cambodia might be said to be moderately low (rather than very low) and improving are political stability (31.1 percentile) and regulatory quality (27.2 percentile). The latter measure is not confirmed by local informants, however, it picks up a decline in formal regulation and its replacement by corruption (which is exceedingly high and worsening), rather than a real improvement in the business atmosphere.

Political stability in Cambodia enjoys a markedly higher percentile ranking than it did in 1996 (10.4 percentile), jumping to the 30th percentile beginning in 2000. This was following Cambodia's second national election which saw the return of Prince Norodom Ranaridh to Cambodia after having been exiled following the 5-6 July 1997 events. $^{26}$ Regulatory quality has seen constant performance in the low to mid 30th percentile for much of this past decade except for 2000 in which it actually 


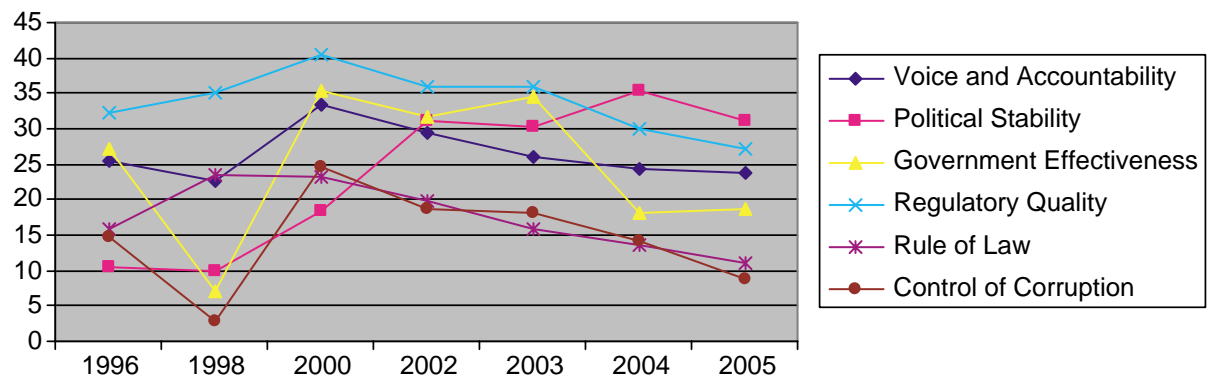

Figure 1 Percentile Rankings on Kaufmann et al's Six Dimensions of Governance 1996-2005. Source: Kaufmann et al. (2006).

reached 40.4 percentile - the year following the implementation of an International Monetary Fund-endorsed value added tax and the resumption of aid that shored up Cambodia's finances considerably. In 2000, after the events of 5-6 July 1997 that led to the suspension of aid from Germany and the United States in 1998 (United Nations, 2000), Cambodia was ranked at the 18.4 percentile for political stability. Likewise for regulatory quality - a dimension that was then in the 30th percentile range. This is consistent with the Mostly Free rating the Heritage Foundation has given the economy from 26.3 in 2000 to 16.8 in 2002 to 13.3 in $2004 .{ }^{27}$ Likewise, the rule of law saw little by way of improvement. It languished in the mid 10th to low 20th percentile, turning in its worst performance in 2005 with a dismal 11.1 percentile. Government effectiveness in contrast saw large fluctuations in rankings throughout the nine-year period, but is now ranked below where it started in 1996, settling for both 2005 and 2004 at the 18th percentile. This is likely tied to worsening control of corruption and rule of law. Finally, voice and accountability has seen mixed performance, peaking in 2000 at the 33.3 percentile, but otherwise remaining in the low to mid 20th percentile for all the other years.

\section{Survey Findings}

The above results which show how Cambodia performed on six dimensions of governance can now be compared and contrasted with donor success in these same dimensions of governance. The survey results which asked for donor success in these dimensions of governance show that aside from political stability and voice and accountability, the informants felt that donors had in fact failed to effect change in the government (with control of corruption being the absolute worst by far with only $7 \%$ rating donor success as medium to very high). The summary statistics for the informants' ratings concerning donor success across the six Kaufmann dimensions of governance are shown in Table 3.

Political stability has the least 'none' to 'poor' ratings and the most 'high' to 'very high' ratings, making it the best ranked dimension of governance in which donors are evaluated as having succeeded. A distant second, numerically, is voice and 
Table 3 Informants' Ratings on Donor Success

\begin{tabular}{|c|c|c|c|c|c|c|c|c|c|c|}
\hline & None & Poor & Med. & High & $\begin{array}{l}\text { Very } \\
\text { high }\end{array}$ & Total & $\begin{array}{c}\text { None } \\
\text { to } \\
\text { poor }\end{array}$ & $\begin{array}{l}\text { High } \\
\text { to } \\
\text { very } \\
\text { high }\end{array}$ & $\begin{array}{c}\text { Med. } \\
\text { to } \\
\text { very } \\
\text { high }\end{array}$ & Rank \\
\hline $\begin{array}{l}\text { Voice and } \\
\text { accountability }\end{array}$ & $\begin{array}{l}9 \% \\
4\end{array}$ & $\begin{array}{l}44 \% \\
19\end{array}$ & $\begin{array}{l}35 \% \\
15\end{array}$ & $\begin{array}{l}12 \% \\
5\end{array}$ & $\begin{array}{l}0 \% \\
0\end{array}$ & 43 & $\begin{array}{l}53 \% \\
23\end{array}$ & $\begin{array}{l}12 \% \\
5\end{array}$ & $\begin{array}{l}47 \% \\
20\end{array}$ & 2 \\
\hline $\begin{array}{l}\text { Political } \\
\text { stability }\end{array}$ & $\begin{array}{c}10 \% \\
4\end{array}$ & $\begin{array}{l}24 \% \\
10\end{array}$ & $\begin{array}{l}31 \% \\
13\end{array}$ & $\begin{array}{l}31 \% \\
13\end{array}$ & $\begin{array}{l}5 \% \\
2\end{array}$ & 42 & $\begin{array}{l}33 \% \\
14\end{array}$ & $\begin{array}{l}36 \% \\
15\end{array}$ & $\begin{array}{l}67 \% \\
28\end{array}$ & 1 \\
\hline $\begin{array}{l}\text { Government } \\
\text { effectiveness }\end{array}$ & $\begin{array}{c}16 \% \\
7\end{array}$ & $\begin{array}{l}53 \% \\
23\end{array}$ & $\begin{array}{l}28 \% \\
12\end{array}$ & $\begin{array}{l}2 \% \\
1\end{array}$ & $\begin{array}{l}0 \% \\
0\end{array}$ & 43 & $\begin{array}{l}70 \% \\
30\end{array}$ & $\begin{array}{l}2 \% \\
1\end{array}$ & $\begin{array}{l}30 \% \\
13\end{array}$ & 4 \\
\hline $\begin{array}{l}\text { Regulatory } \\
\text { quality }\end{array}$ & $\begin{array}{c}20 \% \\
8\end{array}$ & $\begin{array}{l}51 \% \\
21\end{array}$ & $\begin{array}{c}22 \% \\
9\end{array}$ & $\begin{array}{l}7 \% \\
3\end{array}$ & $\begin{array}{l}0 \% \\
0\end{array}$ & 41 & $\begin{array}{l}71 \% \\
29\end{array}$ & $\begin{array}{l}7 \% \\
3\end{array}$ & $\begin{array}{l}29 \% \\
12\end{array}$ & 3 \\
\hline Rule of law & $\begin{array}{l}33 \% \\
14\end{array}$ & $\begin{array}{l}55 \% \\
23\end{array}$ & $\begin{array}{l}10 \% \\
4\end{array}$ & $\begin{array}{l}2 \% \\
1\end{array}$ & $\begin{array}{l}0 \% \\
0\end{array}$ & 42 & $\begin{array}{l}88 \% \\
37\end{array}$ & $\begin{array}{l}2 \% \\
1\end{array}$ & $\begin{array}{l}12 \% \\
5\end{array}$ & 5 \\
\hline $\begin{array}{l}\text { Control of } \\
\text { corruption }\end{array}$ & $\begin{array}{l}60 \% \\
26\end{array}$ & $\begin{array}{l}33 \% \\
14\end{array}$ & $\begin{array}{l}5 \% \\
2\end{array}$ & $\begin{array}{l}2 \% \\
1\end{array}$ & $\begin{array}{l}0 \% \\
0\end{array}$ & 43 & $\begin{array}{l}93 \% \\
40\end{array}$ & $\begin{array}{l}2 \% \\
1\end{array}$ & $\begin{array}{l}7 \% \\
3\end{array}$ & 6 \\
\hline
\end{tabular}

The question asked: 'For each of the above six dimensions of governance, please indicate whether you believe that the donor community as a whole has succeeded in stimulating positive changes in Cambodia or if aid, in effect, is given despite government refusal to change (for example, because of massive poverty or the country's tragic Khmer Rouge legacy). The score below should therefore reflect "donor success" at effecting change in the government.'

Note: the top percentage indicates total informant ratio; the bottom number represents actual number of informants selecting the rating.

Source: results of author's survey.

accountability, although the informants qualified their rankings with a number of comments suggesting that, for a country without a history of democratic governance, Cambodia had come a long way. Rankings for all the informants are consistent when examined under subgroups such as 'Cambodian only', 'Cambodian expatriate', 'foreign expatriate', or combinations thereof. ${ }^{28}$

Given that the 43 professionals working on development in Cambodia found that the donors have been successful in ensuring political stability and to a lesser extent in voice and accountability is an important outcome of the last decade of Cambodian reconstruction and development. That government effectiveness and regulatory quality have seen mixed success is troubling but not surprising given the lack of human capital in the country and the need for state-building in the early post-conflict period. Unfortunately, with the authorities' lack of political will to curb corruption and unwillingness to reign in impunity, the donors' failure in effecting control of corruption and rule of law was laid bare as shown in the results of the survey. Indeed, as can be seen from the comments on ratings of 'none' and 'poor' for control of corruption, some informants suggest that donors have enabled corruption to 
increase. A foreign expatriate manager and advisor with six years' experience in donor and local NGOs who has researched and taught in Cambodia concurred with hypothesis (b) (namely, that high indebtedness and a high poverty rate put great pressure on donors to give even when the governance situation is disappointing) and argued that 'Donors have no real incentive to curb corruption, because they are not held accountable, nor are their activities very transparent. Donors are part of the problem of corruption in Cambodia', while another foreign expatriate manager and advisor with a decade's experience with donor, local and international NGOs who has worked on research and advocacy added that donors 'don't control corruption in their own practices'. Referring to corruption, a foreign expatriate manager with 11 years' experience in an international NGO commented that donors 'encourage it and support it at every opportunity'.

A foreign expatriate manager with over three years' experience with a donor agency wanted to rate donor success in control of corruption as a negative 10 if possible. Those who rated donor success as 'poor' did not mince their words either. A foreign expatriate manager and advisor with seven years' experience in an international NGO and a Cambodian manager with four years' experience with a donor agency agreed on the absence of prosecution for corruption while a foreign expatriate manager with a dozen years' experience with a membership organisation of local and international NGOs specifically stressed two recent incidents involving the World Food Programme (WFP) (on Food-for-Work) and the World Bank (on demobilisation). Indeed, six other informants named the World Bank as being unsuccessful in control of corruption, despite four mentions of the World Bank being successful by others. ${ }^{29}$ Meanwhile, two other informants cited the WFP as being unsuccessful in controlling corruption. Both cases are studied in greater detail in the fifth section. Given this nuanced, multidimensional perspective of donor success towards effecting change in governance, the roles donors have played in Cambodia more generally (and where applicable specific dimensions can be addressed) during the last decade is the subject of the next section.

\section{Governance and Aid Effectiveness: Explaining the Results}

Donors have played the role of doting parent and occasional disciplinarian to Cambodia. The embarrassment of inaction during the Khmer Rouge genocide has lowered their willingness to demand too much of Cambodia, making allowances for the burden of its history. They frequently qualify Cambodia's lack of progress with its terrible past and the absence of human capital following the Khmer Rouge period. ${ }^{30}$ Indeed, as has been argued by McCargo (2005: 107) 'Given Cambodia's recent history of bloodthirsty ideological dictatorship and civil war, the bar for what constitutes improvement is extremely low. Hun Sen and his cohorts "get away with" authoritarianism because strongman rule is a lesser evil than mass murder.' 


\section{Defenders of the Faith: Voice and Accountability vs. Political Stability}

Elections are the culmination of a democratic process. In Cambodia, elections seem to be the process in the eyes of the international community. This is an important lesson the Cambodian People's Party (CPP) learned after 1993 when it lost to the Funcinpec Party. A brokered solution to the subsequent impasse called for no winners and no losers in the form of two Prime Ministers from each party. As McCargo (2005: 99-100) has argued, 'What happened under UNTAC in 1993 was the beginning of a pattern in which Hun Sen used the outward show of electioneering to legitimize the status quo rather than let power change hands', adding that 'Elections in Hun Sen's Cambodia have become an exercise in political theater that the CPP uses to legitimize its power'. Indeed, the threshold for free and fair elections is not particularly high, and varies according to observers. Observers may visit only for the elections, unaware of the presence of an atmosphere of intimidation.

This may also help to explain why donor success in voice and accountability was perceived by the informants as relatively good with $47 \%$ rating it as medium to very high. In 1996, the leader of the European Union (EU) delegation, Italian Ambassador Leopoldo Ferri de Lazara, said: 'If Cambodia is able to maintain [the] present political framework until the 1998 national elections, a democratic and normal life will have been achieved after years of war and instability' (quoted in REC, 1997). With respect to human rights and democracy, the Ambassador said:
E.U. policy [is] to allow sovereign countries to reach democratic status by their own means. This is a situation where the international community should help the Cambodians rather than condemn them ... Our approach on human rights is that we feel if we continue our development aid we will see results. (Ibid.)

A retired diplomat (2003) described 'crossing spades' subsequently with the Counsellor for the EU Delegation based in Bangkok: 'he challenged my assertion that Cambodia was not yet a democracy and dismissed the Cambodian opposition as 'trouble makers' for asking the [National Election Committee] to affect the recounting of votes at some places during the 1998 election'.

This view was reconfirmed in 2003 by then United Nations Resident Coordinator and Resident Representative of the United Nations Development Programme, Dominique McAdams:

Based on the criteria used to assess a country's degree of democratic participation, Cambodia is a free and steadily progressing country. This assessment is based on three main indicators: elections, a multiparty parliamentary system and freemedia ... When it comes to political parties, very frankly, I don't know any other Asian country that would tolerate the level of strong words used by the MP Sam Rainsy in his media papers or whatever... That the government may not have performed as well on judiciary reform or the issue of corruption may be the result of an over-ambitious reform agenda. (quoted in Doyle, 2003) 
With respect to political stability, the respondents judged donor success in this area of governance as highest with $67 \%$ rating it medium to very high. Indeed, there was a sense among the informants that a Faustian pact was made to promote stability at the expense of democracy. Among the ratings for high to very high, the comments attached were full of sarcasm like those of a foreign expatriate manager, advisor, researcher and teacher with six years' experience in donor and local NGOs who wrote 'donor funds have helped prop up an increasingly autocratic, despotic state' or a foreign expatriate donor official with six years' experience in Cambodia argued that 'donors reinforce [the] status quo' or a foreign expatriate manager, advisor, researcher, and advocate with a decade's experience with donor, local and international NGOs who claimed that 'the international community has and continues to happily underwrite authoritarianism (which in the long run isn't terribly stable, but donors don't object to the incremental expressions, such as the murder of Members of Parliament, etc.)'. A foreign expatriate manager with 11 years' experience in an international NGO added that 'donors have succeeded at making the current government ministers into some of the richest, most secure officials of any "democracy" in the world'. Other informants were truly genuine in their praise. A foreign expatriate advisor with six years' experience in a donor agency said, 'Donor assistance to the election process has resulted in three relatively successful national elections and the commune election. Violence has decreased in each successive election and processes improved.' Finally, one particularly nuanced response from a foreign expatriate manager with a dozen years' experience with a membership organisation of local and international NGOs was as follows:

Cambodia could not have extracted itself from its civil war without the help of donors, in particular the UNTAC and the governments which supported it. It should be remembered, however, that donors had previously fueled the civil war, and much of the credit for an end to the fighting lies with the actions of the Hun Sen government, and (then) Prince Sihanouk. Donors also contributed to a resolution of the 1997 crisis by pressuring the Hun Sen-controlled government to allow the return of Prince Ranariddh before the 1998 elections.

In late 2005, the arrests of human rights and civil rights activists were based on the pretext of preventing chaos and instability following Cambodia's signing of a supplemental border treaty with Vietnam. After one of the activists was released, he issued a statement that spoke to the perceived tension between stability and voice. He argued that stability was used to justify the silencing of dissenting voices and that, while he agreed that stability is important, 'stability is not created by the short-term stifling of dissenting views; in fact, such stifling has the opposite effect' as 'stability is achieved by the long-term ability of a society to tolerate multiple voices and views, and incorporate those differing perspectives into the ongoing development that all democratic societies experience' (Yeng, 2006). Four days later, on the occasion of the dedication of the new United States Embassy in Phnom Penh and hours following the release of four human rights activists from detention, its ambassador would quote 
Benjamin Franklin's dictum: 'Those who would give up essential liberty to purchase a little temporary safety deserve neither liberty nor safety'.

\section{Rule of Law: Capture of Justice Institutions}

With respect to the rule of law (ROL) finding of the survey which is the second least successful donor-supported dimension of governance with $12 \%$ rating it medium to very high, Steve Golub (2003: 3) criticises the 'Rule of Law Orthodoxy' which he identifies as 'most prominently practiced by multilateral development banks' and defines it as a "top-down," state-centered approach [that] concentrates on law reform and government institutions, particularly judiciaries, to build business-friendly legal systems that presumably spur poverty alleviation'. Using Cambodia as an example, he explains:
A key assumption of ROL orthodoxy is that the judiciary is central to serving society's legal needs: Unless we fix the courts, many other legal reforms will fail. As the World Bank's Legal Vice Presidency puts it, 'The rule of law is built on the cornerstone of an efficient and effective judicial system'... . the Asian Development Bank asserts that 'although a daunting task, Cambodia has no alternative other than to overhaul the current judicial system if it is to lay a strong foundation for the nation's future development. These claims tie in with related assumptions that neither alternative roads to justice nor dysfunctional judiciaries are usable. This package of assumptions, however, is fatally flawed. (Ibid.: 15)

In 2004, the World Bank stopped its traditional legal and judicial reform programme in Cambodia because of an absence of political will and the likelihood that new justice institutions would be captured by the authorities. A foreign expatriate manager and advisor with six years' experience in donor and local NGOs who has researched and taught in Cambodia put it eloquently:

The state, including the army and the privileged elite are responsible for most of the crimes, both violent (e.g. land-grabbing) and non-violent (e.g. corruption, resource exploitation). Donor support has enhanced the state's impunity. The absolute inability of donor support to affect positive change in the justice system is a case in point.

A singular exception to the donors' failure in rule of law has been the Arbitration Council, an independent tribunal established by law to decide on collective labour disputes which cannot be settled by conciliation. The Arbitration Council was established in 2003 according to the provisions of the 1997 Labour Law at the behest of the United States which required Cambodian garment factories to meet Cambodian labour standards (more than 60\% of Cambodia's export dollars are garments that go to the United States). The Arbitration Council's founders were given the choice of being either independent without binding rulings or not independent with binding rulings. They chose to be independent, believing that the Arbitration Council's legitimacy would grow over time and that participants would voluntarily 
choose that the rulings be binding. Without threatening the political elites' hold on power, the Arbitration Council has succeeded where others have failed. As a result, the World Bank initiated a Justice for the Poor programme in 2005 to explore the possibilities of alternative dispute resolutions in land conflicts.

\section{Control of Corruption: Cambodia's Problem and the Donors'}

In tandem with the disappointing donor success in rule of law has been even worse donor performance in effecting Cambodia's control of corruption. Corruption consumes a significant portion of the economy - possibly as much as the entire aid budget each year. To combat it, Cambodia has been drafting an anti-corruption law since 1994. However, this law has not been passed by the National Assembly and while 'Many use this as an explanation for the widespread corruption in Cambodia and the culture of impunity that exists ... a law is only the first stage of reform' (MacLean, 2006: 9). The results of a survey on governance and corruption in 2000 prepared by the World Bank in response to a request by the authorities for technical assistance for capacity building in enhancing governance and fighting corruption, found that public corruption is perceived as a leading problem for citizens and enterprises of all types with some functions of government, such as the judiciary, revenue collection bodies, and bodies managing public assets rated particularly poorly (World Bank, 2000: iv). A more recent survey of corruption shows that unofficial payments $^{31}$ amount to $5.2 \%$ of the surveyed firms' gross revenue (World Bank, 2004b), more than twice that of Bangladesh, Transparency International's bottom performer on the Corruption Perceptions Index (CPI) of 2004. ${ }^{32}$ Cambodia was ranked for the first time in the 2005 CPI at 130 out of $158,{ }^{33}$ and fell further in the 2006 CPI to 151 out of 166 countries. ${ }^{34}$ Corruption has been estimated at $\$ 120$ million per year (World Bank, 2004b) and between $\$ 300-500$ million per year by Calavan et al. (2004). This latter figure suggests that up to $12.5 \%$ of Cambodia's circa four billion dollar gross domestic product is possibly consumed by corruption.

A foreign expatriate manager and advisor with four years' experience in donor and international NGOs in Cambodia complained that the 'Situation has deteriorated from when I first worked in Cambodia in 1990', while a Cambodian expatriate manager with a decade's experience in development quipped that 'The anticorruption bill is a joke' because 'The whole government system, which is based on patronage mentality, has prospered out of control due to corruption that has benefited a select few. It would be too much to expect that the top would do anything serious to cut their own throat and life line.' A Cambodian expatriate manager with a seven years' experience in an international NGO and a National Institution called on more 'international pressure' while a foreign expatriate manager and advisor with five years' experience with a donor agency went so far as to claim that donors 'May have made corruption worse'. Clearly, something has gone terribly wrong with the donors and the RGC when it comes to corruption and the following two cases of donor 
handling of corruption in 2003-2005 are instructive: (1) the WFP and Food-for Work and (2) the World Bank and Demobilisation.

\section{Case-Study 1: The World Food Programme and Food-for-Work}

In 2004, the WFP reported that more than two million dollars' worth of rice had been diverted from its Food-for-Work (FFW) scheme. The approach was at first very public, with a front-page article in the Phnom Penh Post (Woodd, 2004b) and an interview with the then WFP Representative in Cambodia (Woodd, 2004a). It included prior consultation with Cambodia's largest bilateral donor and assurances of support by that donor as leverage on the RGC. At the time, the WFP Representative put her foot down: 'If [the government] did not accept anything then we would have to seriously look at our future in Cambodia' (quoted in McKenny, 2005). The RGC quickly accepted the terms, took responsibility and agreed to repay in principle, following its own investigation.

Unfortunately, the \$2 million figure was then disavowed by the WFP which made clear to the RGC that the amount in question was negotiable. A year to the day, on 28 February 2005, the RGC agreed to pay only $\$ 900,000 .^{35}$ The WFP had suspended FFW for the duration, but continued all other activities in order not to hurt the 'hungry poor' (quoted in Cochrane, 2005). The agreement came coincidentally after the WFP announced that it would distribute 1,500 metric tons of rice to the drought affected population. There was no apparent rallying around the WFP by other donors, and no press releases were found either on the WFP's global website ${ }^{36}$ or its local one $\mathrm{e}^{37}$ concerning this matter through mid-March 2005. The case was further complicated by the WFP Representative's coincidental and unrelated departure from Cambodia for another posting and allegations of the WFP local staff's own complicity in the corruption (evidence of which was used as a foil for criticism of the RGC). While some local staff of the WFP did not have their contracts extended, no government official was ever punished. One would hope that the lesson learned from this will be the importance of credibility in issuing ultimatums, continuity, and consistency in applying pressure and holding firm.

\section{Case-Study 2: The World Bank and Demobilisation}

In contrast, the case of the World Bank saw somewhat better results even though its initial approach was more muted. ${ }^{38}$ The World Bank initially took a very low-key approach for two years with respect to the declaration of mis-procurement in a demobilisation project with the RGC. The Integrity Department of the World Bank investigated certain procurement irregularities concerning a World Bank-financed $\$ 6.9$ million contract for the supply and maintenance of motorcycles. Misprocurement was declared on the contract on 26 June 2003 and the World Bank sought repayment of $\$ 2.8$ million. Seeing no progress, it was then reported in the media that a letter was sent by the World Bank's Vice President for East Asia and the 
Pacific which allegedly threatened that if the reimbursement did not take place by 15 February 2005, its entire portfolio of more than a dozen World Bank-funded development projects would be suspended. This quickly produced results with the immediate repayment of $\$ 2.8$ million.

At an impromptu press conference on 21 January 2005, the Prime Minister suggested to reporters that the World Bank had brought into the tender process the private firms responsible for the corruption. Minister of Economy and Finance Keat Chhon was more conciliatory when he was earlier interviewed by the Associated Press. He said 'It is regretful for me that such a problem has occurred. This was because there were loopholes in the implementation ... We must work to build good governance, so others [will] stop suspecting that corruption was committed' (quoted in Associated Press, 2005).

\title{
Learning from the Cases
}

To be sure, the World Bank's large size, its role as lender of last resort, and its stature as co-chair of annual CG meetings gave it more leverage than the WFP, but the case also suggests that the World Bank's threat to suspend its entire portfolio was credible while the WFP's threat to examine its future in Cambodia lacked credibility. ${ }^{39}$ Learning from past lessons elsewhere, the World Bank already knew by 2004 that:

\begin{abstract}
Experience in other countries in which donors have been criticized for past inaction on corruption and poor governance suggests some basic internal changes that donors can undertake - greater information disclosure, strengthened controls and supervision, engagement of communities and civil society organizations in project design and supervision as the norm, and better enforcement when abuses are discovered. These measures can significantly reduce the opportunities for misuse of ODA and, in doing so, contribute to clarifying the distinction between public and private resources. (World Bank, 2004a: 122)
\end{abstract}

In the case of Cambodia, the World Bank failed to follow its own advice. It was generally mute about its actions, disclosing little information in contrast to the WFP. However, when it came to enforcement after the abuses were discovered, the World Bank may have had the upper hand. After all, food is very different from money, and the World Bank's ability to penalise Cambodia through its annual performance-based allocation exercise known as the Country Performance and Institutional Assessment (CPIA), and more immediately by threatening to withhold millions of other project funds, suggests that the authorities had little choice. In refusing the Bank's terms, they would be pennywise, pound foolish.

Indeed, as MacClean (2006: 10) points out, 'A degree of political will for reform exists within the government, but the reality is that those in power have little reason to change a system that has secured them much power and personal wealth'. Furthermore, 'stricter costs imposed by the donor community would serve to pressure the government and effect real change'. These stricter costs materialised in 
early 2005 when the CPIA scores became public for the first time since they were introduced in the late 1970s - something the World Bank clients themselves had lobbied hard against - making the instrument more credible as a deterrent against poor governance performance. In February 2005, James Wolfensohn, then President of the World Bank, declared, 'We have reduced our lending to Cambodia - as a response to the poor performance on governance indicators-but we have not reduced our commitment, nor our efforts to push for the kinds of reforms that are needed to bring about a better life for all Cambodians' (quoted in World Bank, 2005a). His announcement was based on the 2004 CPIA score for Cambodia, which had already been revealed to the authorities in a letter dated 26 July 2004 . Finally, it is worth noting that even in this 'successful' case, those who committed the corrupt acts neither reimbursed their gains nor were prosecuted. It was the RCG that provided the reimbursement and its budget is de facto donor-supported with fungible aid.

\section{Conclusion}

This article began with a brief review of the literature on how aid can influence governance. Using Boone (1996) as a springboard, it focused on the issues raised by Knack (2001), who found aid dependence to be associated with an increase in corruption, worsening bureaucratic quality, and rule of law. This formed the basis for this case-study on the political economy of aid and governance in Cambodia. The country's challenges in light of high aid dependence and the 'Dutch disease' in the aid sector are elaborated and disappointing development outcomes are examined, particularly in human development. Despite large aid infusions, infant and child mortality and inequality have worsened.

Two questions were posed in this article: (1) what is the relationship between the Kaufmann et al. (2006) scores and the large amounts of ODA Cambodia has received; and (2) can ODA be said to cause the rankings and/or their changes? It would appear that, aside from political stability and to a lesser extent voice and accountability, Cambodia cannot be said to have enjoyed donor success in the other four dimensions of governance. Political stability is the by-product of a peace dividend sowed by the Cambodian stakeholders and nurtured by the international community. The donors and the government were aligned on political stability, and this was clearly the political bargain made in Paris in 1991, to move Cambodia from a state of war to one of peace.

Certainly, with respect to control of corruption and rule of law, it would seem that Cambodia may be further now from progress in these key areas than it was a decade earlier. What is apparent too is that ODA has made it more feasible, at some level, through fungibility, to divert resources and to increase corruption. The country's Kaufmann et al. (2006) ranking for 2005 in the area of regulatory quality (27.2 percentile) is its second best followed by political stability (31.1 percentile) and, according to the Heritage Foundation, it is better than most countries in terms 
of economic freedom. But this of course has masked a trade-off, one that has seen regulations replaced with corruption.

Knack (2001: 326) suggested that 'a larger fraction of aid could be tied or dedicated to improvements in the quality of governance, for example, in the form of programs to establish meritocratic bureaucracies and strong, independent court systems. While judicial independence remains a serious problem in Cambodia, and a meritocratic bureaucracy cannot function in the context of \$20-40 per month salaries, donors like the World Bank have already recognised that alternative justice mechanisms for the poor are needed. On the basis of what has been accomplished to date, however, ODA seems unlikely to be able to deliver large improvements in governance and in some ways may even contribute to its further deterioration. Aid dependence generally is not a positive condition for development.

\section{Acknowledgements}

The author would like to thank an anonymous reviewer, Prof. Jon S. T. Quah, co-editor of the Asian Journal of Political Science, Dr. David K. Leonard of the University of California at Berkeley, Chamnan Lim of Syracuse University, Clay Wescott of the World Bank, and seminar participants at Syracuse University, the University of Ottawa, Yonsei University, the Naval Postgraduate School, and the 2006 International Conference on Social Science Research in Vancouver, Canada, for their helpful comments and support on earlier drafts. This material is based on the doctoral dissertation research supported by the University of California at Berkeley, the Council of American Overseas Research Centers/Center for Khmer Studies, and would not have been possible without the help of the 43 informants who answered the author's April/May 2005 survey on aid and governance in Cambodia.

\section{Notes}

[1] This article uses 'ODA' and 'aid' interchangeably.

[2] ISI Web of Science tracked 63 separate references in refereed journals that cite Boone (1996).

[3] Aid dependence is a concept that, while broadly understood, has been defined in a variety of ways. Lensink and White (1999: 13) define it as: 'A country is aid dependent if it will not achieve objective X in the absence of aid for the foreseeable future'. Riddell (1996: 24) has called it 'that process by which the continued provision of aid appears to be making no significant contribution to the achievement of self-sustaining development'. Sobhan (1996: 122) defines it as 'a state of mind, where aid recipients lose their capacity to think for themselves and thereby relinquish control'. Bräutigam (2000: 2), from whom the previous definitions were gathered, envisages aid dependence as 'a situation in which a country cannot perform many of the core functions of government, such as operations and maintenance, or the delivery of basic public services, without foreign aid funding and expertise'. In turn she uses aid intensity as a proxy for aid dependence, aid as a percentage of GNP, central government expenditure, current revenue, gross domestic investment, or imports.

[4] The failure on rule of law is of another category - it shows insufficient donor attention to the issue and/or the application of dysfunctional models of institutional development. 
[5] For an excellent and current survey of the macroeconomic effects of foreign aid, see Harms and Lutz (2004).

[6] Bräutigam (1992: 1) had already noted that 'Much of the current donor discussion of governance takes place outside of a historical or theoretical context' and was a first attempt to place governance 'within recent political science, development management, and institutional economics literature'.

[7] Harms and Lutz (2004: 16) note that when Burnside and Dollar (1997: 847) write 'foreign capital has not raised growth rates in the typical poor country', they refer only to Peter Boone's 1996 European Economic Review article and the 1995 London School of Economics working paper version from which the EER article is based, but not to any other studies.

[8] As Harms and Lutz (2004) have subsequently noted, however, many of the 29 papers surveyed were 'outdated'.

[9] Knack co-authored with Bräutigam a paper on aid and governance in sub-Saharan Africa, finding that 'high levels of aid are associated with declines in the quality of governance' (Bräutigam and Knack, 2004: 277).

[10] This was an outgrowth of Burnside and Dollar's then working paper released in 1997 since David Dollar was a director in the World Bank's Research Department.

[11] Funcinpec is a French acronym for United National Front for an Independent, Peaceful, and Cooperative Cambodia, a royalist political party formed by Sihanouk.

[12] UNTAC drew delegated authority from the Supreme National Council composed of all parties to the conflict and chaired by Sihanouk.

[13] Indeed, a perusal of the titles of World Bank reports published in 1994-1997 tells the story of transition: From Rehabilitation to Reconstruction (World Bank, 1994); Rehabilitation Program (World Bank, 1995); From Recovery to Sustained Development (World Bank, 1996); and Progress in Recovery and Reform (World Bank, 1997).

[14] According to World Bank (1998: 130), 'fungibility' is defined as the possibility for aid recipient countries to reduce their own resources in the sector that receives aid and transfer them to other sectors of the budget.

[15] According to Aristide (2000: 13), Brian Atwood, then Administrator of USAID, testified to Congress 'that 84 cents of every dollar of aid goes back into the US economy in goods and services purchased. For every dollar the United States puts into the World Bank, an estimated $\$ 2$ actually goes into the US economy in goods and services'.

[16] The origin of the phrase 'governance is a sine qua non' can be traced at least as far back as United Nations (1996).

[17] Sok An was at the time Senior Minister, Minister in charge of the Office of the Council of Ministers, and Chairman of the Council for Administrative Reform.

[18] To compare apples to apples, the World Bank took the accessible part of the country in $1993 / 1994$, ascribing to it the original $39 \%$ national poverty rate, and derived a $28 \%$ poverty rate for the same area in 2004.

[19] Unusable responses included four that did not contain any answers and one that did not meet the three-year criteria (the informant reported 1.5 years' experience as a foreign expatriate Advisor working for the RGC). One informant declined to rate donor success numerically.

[20] More than 300 emails were sent asking recipients to respond, or to refer the author to individuals they might know who met the three-year criteria. Responses online were completely anonymous save for an optional question at the end of the survey requesting an email address for follow-up.

[21] This is akin to a snowball sample.

[22] This includes references to RGC, 'Parliament', and 'National Institution'.

[23] Informants indicated, for instance: National Institution, Parliament, university, and international organisation. 
[24] Of those informants, a Cambodian specialist with nine years' experience with a donor agency replied via email sending ratings annotated with: 'My life has... gone through several regimes and governance styles, I feel frustrated or pessimistic about the current governance system. I could not have much hope that the donors could play more [of a] role in this matter for immediate impact, but it may be useful/helpful for building awareness and confidence to our champion citizen or civil servants in a medium term or long term impact. However, we also have to balance our thinking that given the fact that the foreign Aid/ assistance has a limited immediate impact on governance matter, and if we deny foreign assistance, how much the poor citizen will suffer/benefit from the withdrawal of the donors or international communities from our country? In conclusion, the government/political will in making the reform in its governance system determine the achievement of the Aid effectiveness for the quality of governance in Cambodia.'

[25] Informants described, among other professions, 'political appointee' and 'donor official', for example.

[26] On 5-6 July 1997, then First Prime Minister Norodom Ranariddh was ousted from power by Second Prime Minister Hun Sen. This resulted in more than 70 extrajudicial killings of mostly Funcinpec civilian loyalists. Although the precise details may never come to light, the general storyline is that in the lead-up to the events, a power struggle between Funcinpec and the CPP emerged in recruiting senior Khmer Rouge defectors. This led, for all intents and purposes, to a coup d'etat. Forces loyal to the Second Prime Minister launched violent and sustained attacks against forces loyal to the First Prime Minister (claiming that the former was ready to take sole power) in Phnom Penh and the surrounding area (Amnesty International, 1997).

[27] Heritage Foundation (2005) rates Cambodia as 'Mostly Free' in terms of economic freedom with an overall score of 2.89 (ranked 63 just above Mexico), and the country ranks higher than Thailand (71), Vietnam (137), and Laos (150) out of 161 countries.

[28] Whether there are differences in views among individuals who worked in management, as advisors, in education/research or in some other capacity, is difficult to determine because so many informants cross-listed themselves as functioning in one, two or more capacities. The same is true across government, donors, and NGOs (whether local or international), where quite a few informants had worked for more than one type of organisation over years.

[29] One pointed to the Social Fund, a Bank project that has now closed, and another referred to International Financial Institutions in general (which includes the World Bank).

[30] According to Vachon (2005), Robert Hagemann, then Resident Representative for the IMF, noted that it has only been since 1998 that Cambodia has been at peace, saying 'It's taken this time to instill an amount of confidence [in peace] for people to begin planning ahead'.

[31] This is the preferred phraseology of the authorities, while it is more commonly known as a bribe tax. Prior to being released, World Bank (2004b) saw all instances of 'bribe tax' replaced with 'unofficial payments' at the behest of the RGC. However, the find-and-replace function missed one instance in 'Annex III: Methodology: Productivity and Investment Climate Survey' on page 110.

[32] Bangladesh was tied with Haiti in last place at 145 out of 145. Available at: http://www. transparency.org/cpi/2004/cpi2004.en.html\#cpi2004.

[33] The 2005 CPI rankings are available at: http://www.transparency.org/policy_and_research/ surveys_indices/cpi/2005.

[34] The 2006 CPI rankings are available at: http://www.transparency.org/policy_research/surve ys_indices/cpi/2006.

[35] With less than half the initial amount claimed repaid, the penalty for corruption appears to have gone on sale.

[36] Click on 'Press Releases' at http://www.wfp.org/country_brief/indexcountry.asp?country=116.

[37] See http://www.un.org.kh/wfp. 
[38] Prior to 1996, when the 'c-word' (corruption) was seen as off-limits and political, the Bank's approach to corruption was ridiculed as the three-monkeys policy: see no evil, hear no evil, speak no evil (see Bretton Woods Project, 2003).

[39] Richardson (2005) quotes a Bank staff member as having said in July 2002: 'As long as 60 percent of the money gets where it's supposed to go, that's good enough for me'. On this basis, she argues that such staff members should have been made to pay $40 \%$ of the $\$ 2.8$ million.

\section{References}

ActionAid (2005). Real Aid: An Agenda for Making Aid Work. ActionAid International. Available at: http://www.actionaidusa.org/Action\%20Aid\%20Real\%20Aid.pdf.

Amnesty International (1997). 'Cambodia: Escaping the Killing Fields?' AI Index: ASA 23/038/1997, News Service 178/97, 23 October. Available at: http://web.amnesty.org/library/Index/ENGA SA230381997? open\&of = ENG-KHM.

Aristide, J.-B. (2000). Eyes of the Heart: Seeking a Path for the Poor in the Age of Globalization. Monroe, ME: Common Courage Press.

Associated Press (2005). 'Cambodia Says It Will Repay Aid Funds', Associated Press, 19 January.

Boone, P. (1996). 'Politics and the Effectiveness of Foreign Aid', European Economic Review, 40: 289-329.

Bräutigam, D. (1992). 'Governance, Economy, and Foreign Aid', Studies in Comparative International Development, 27 (3): 3-25.

Bräutigam, D. (2000). Aid Dependence and Governance, Report prepared for the Division for International Development Cooperation, Ministry for Foreign Affairs, Sweden, Expert Group on Development Issues. Stockholm: Almqvist and Wiksell International. Available at: http:// www.egdi.gov.se/pdf/20001pdf/2000_1.pdf.

Bräutigam, D. and Botchwey, K. (1999). 'The Institutional Impact of Aid Dependence on Recipients in Africa', Working Paper WP 1999:1. Bergen: Chr. Michelsen Institute.

Bräutigam, D. and Knack, S. (2004). 'Foreign Aid, Institutions, and Governance in Sub-Saharan Africa', Economic Development and Cultural Change, 52 (2): 255-285.

Bretton Woods Project. (2003). 'Inside the Institutions: How the World Bank Deals with Fraud and Corruption in its Projects', Bretton Woods Project, 21 July. Available at: http://www.bretto nwoodsproject.org/article.shtml?ccmd\%5B126\%5D =x-126-16571.

Burnside, C. and Dollar, D. (1997). 'Aid, Policies, and Growth', Policy Research Working Paper, No. 1777. Washington, DC: World Bank.

Calavan, M., Briquets, S. and O'Brien, J. (2004). Cambodia Corruption Assessment, prepared for USAID Cambodia by United States Agency for International Development and Casals \& Associates, 19 August.

Cochrane, L. (2005). 'Rice Fraud Deal Struck', Phnom Penh Post, 14/08, 22 April-5 May.

Doyle, K. (2003). 'Developing Democracy', The Cambodia Daily, 277, 14-15 June. Available at: http://www.camnet.com.kh/cambodia.daily/selected_features/un_story.htm.

Ear, S. (2005). 'Governance and Economic Performance: Credibility, Political Will, and Reform', Cambodian Economic Review, 1 (1): 17-52. Available at: http://www.cea-cambodia.org/pdf/ Cambodian_Economic_Review_I.pdf.

Ear, S. (2006). 'The Political Economy of Aid, Governance, and Policy-Making: Cambodia As Seen from Global, National, and Sectoral Perspectives', PhD dissertation, Department of Political Science, University of California, Berkeley. Available at: http://csua.berkeley.edu/ sophal.

Ear, S. (2007). 'Does Aid Dependence Worsen Governance?', International Public Management Journal, 10 (3), forthcoming September.

Easterly, W. (1997). 'The Ghost of Financing Gap: How the Harrod-Domar Growth Model Still Haunts Development Economics', Policy Research Working Paper, No. 1807. Washington, DC: 
World Bank. Available at: http://www-wds.worldbank.org/servlet/WDS_IBank_Servlet?pco $\mathrm{nt}=$ details\&eid $=000009265 \_3971110141350$.

Gibson, D. (1993). 'Cambodian Reconstruction Still a Long Way Off', Kyodo News, 31 March.

Godfrey, M., Chan, S., Kato, T., Long, P. V., Pon, D., Tep, S., Tia, S. and So, S. (2000). 'Technical Assistance and Capacity Development in an Aid-Dependent Economy: The Experience of Cambodia', Working Paper 15. Phnom Penh: Cambodia Development Resource Institute.

Golub, S. (2003). 'Beyond Rule of Law Orthodoxy: The Legal Empowerment Alternative', Rule of Law Sereies, Democracy and Rule of Law Project, 41, Washington, DC: Carnegie Endowment for International Peace. Available at: http://www.carnegieendowment.org/files/wp41.pdf.

Hansen, H. and Tarp, F. (1999). The Effectiveness of Foreign Aid, Development Economics Research Group, Institute of Economics, University of Copenhagen. Available at: http://www.econ. ku.dk/derg/papers/Aid_Effectiveness_Disputed.pdf.

Harms, P. and Lutz, M. (2004). 'The Macroeconomic Effects of Foreign Aid: A Survey', Discussion Paper, No. 2004-11, Department of Economics, University of St. Gallen. Available at: http:// www.vwa.unisg.ch/RePEc/usg/dp2004/dp11_har.pdf.

Heritage Foundation (2005). 'Index of Economic Freedom: Cambodia', Washington, DC: The Heritage Foundation. Available at: http://www.heritage.org/research/features/index/country. cfm?id= Cambodia.

Hun, S. (2001). 'Addresses to the 2nd National Conference on the Implementation of the Government's Political Platform for Social Development and Poverty Reduction March 12-14', excerpted in Cambodia New Vision 38, March. Available at: http://www.cnv.org.kh/ cnv_html_pdf/cnv_38.htm.

Kaufmann, D., Kraay, A. and Mastruzzi, M. (2006). 'Governance Matters V: Governance Indicators for 1996-2005', Washington, DC: World Bank, 15 September. Available at: http://www. govindicators.org.

Kaufmann, D., Kraay, A. and Zoido-Lobatón, P. (1999). 'Governance Matters', Policy Research Working Paper, No. 2196. Washington, DC: World Bank, October. Available at: http:// www.worldbank.org/wbi/governance/pubs/govmatters.html.

Keat, C. (2001). 'Presentation by Minister of Economy and Finance at the High-Level Consultations between AusAID and the Royal Government of Cambodia', 16 May. Available at: http:// www.cdc-crdb.gov.kh/cdc/australia_table_contents.htm.

Kenjiro, Y. (2005). 'Why Illness Causes More Serious Economic Damage than Crop Failure in Rural Cambodia', Development and Change, 36 (4): 759-783.

Knack, S. (2001). 'Aid Dependence and the Quality of Governance: Cross-country Empirical Tests', Southern Economic Journal, 68 (2): 310-329.

Lensink, R. and White, H. (1999). Aid Dependence: Issues and Indicators, EGDI Study 1999:2. Stockholm: Ministry for Foreign Affairs. Available at: http://www.egdi.gov.se/pdf/19992pdf/ 1999_2.pdf.

MacLean, L. (2006). National Integrity Systems Transparency International Country Study Report of Cambodia 2006. Berlin: Transparency International. Available at: http://www.transparen cy.org/content/download/12693/125508/version/1/file/Cambodia_NIS_2006.pdf.

McCargo, D. (2005). 'Cambodia: Getting Away with Authoritarianism?', Journal of Democracy, 16 (4): $98-112$.

McKenny, L. (2005). 'WFP-Government Rice Fraud Talks Yield Nothing', Phnom Penh Post, 14/02, 28 January-10 February.

Prescott, N. and Pradhan, M. (1997). A Poverty Profile of Cambodia, Report WDP 373. Washington, DC: World Bank, 31 October. Available at: http://www-wds.worldbank.org/servlet/WDSCon tentServer/WDSP/IB/1997/10/01/000009265_3971126124351/Rendered/PDF/multi_page.pdf.

Retired Diplomat (2003). 'Memoirs of a Retired Diplomat', Chapters 1 and 2, KhmerConnection, 14 August. Available at: http://khmer.cc/community/t.c?b=13\&t=1331. 
Richardson, S. (2005). 'Cambodia, the World Bank, and Demobilization', in The Nation. Bangkok: The Nation Group.

Riddell, R. (1996). 'Aid Dependency', in Sida, Aid Dependency: Causes, Symptoms and Remedies, Project 2015. Stockholm: Sida.

Royal Embassy of Cambodia (REC) (1997). 'European Union Appealed for Unconditional Aid to Cambodia', Newsletter of the Royal Embassy of Cambodia. Washington, DC: Royal Embassy of Cambodia, August. Available at: http://www.embassy.org/cambodia/newsletter/newslett97/ aug.htm.

Royal Government of Cambodia (RGC) (2004). 'Address by Samdech Hun Sen on the "Rectangular Strategy" for Growth, Employment, Equity and Efficiency: First Cabinet Meeting of the Third Legislature of the National Assembly at the Office of the Council of Ministers', Phnom Penh: Royal Government of Cambodia, 16 July. Available at: http://www.car.gov.kh/relate dtopic/rectangular\%20strategy.htm.

Sobhan, R. (1996). 'Aid Dependence and Donor Policy: The Case of Tanzania with Lessons from Bangladesh's Experience', in Sida, Aid Dependency: Causes, Symptoms and Remedies, Project 2015. Stockholm: Swedish International Development Agency.

Sok, A. (2003). 'Interim Consultative Group Meeting Speech on Administrative Reform by H.E. Sok An Senior Minister, Minister in Charge of the Office of the Council of Ministers, and Chairman of the Council for Administrative Reform', 28 January. Available at: http:// www.car.gov.kh/officialstatement/Sokan_003.html.

United Nations (1992). 'The Secretary-General's Consolidated Appeal for Cambodia's Immediate Needs and National Rehabilitation', United Nations Transitional Authority in Cambodia (UNTAC), May.

United Nations (1996). 'Public Administration and Development Report of the Secretary-General', United Nations Economic and Social Council, 8 March. Available at: http://www.un.org/ documents/ecosoc/docs/1996/e1996-7.htm.

United Nations (2000). United Nations Development Assistance Framework (UNDAF) Cambodia: 2001-2005. Phnom Penh: United Nations. Available at: http://www.un.org.kh/UNDAF/ 13-annex_c-oda_overview.pdf.

Vachon, M. (2005). 'Cambodian Economy and Psychology Still Affected by Suffering Under the Khmer Rouge', The Cambodia Daily, 16-17 April. Available at: http://www.cambodiangen ocide.org/psychology_cdaily.htm.

Woodd, R. (2004a). 'Action Swift against Scamsters, Says WFP', Phnom Penh Post, 13/19, 10-23 September.

Woodd, R. (2004b). 'Government in \$2 Million Rice Fraud', Phnom Penh Post, 13/18, 27 August-9 September.

World Bank (1994). From Rehabilitation to Reconstruction, Report No. 12667. Washington, DC: World Bank, 2 October. Available at: http://www-wds.worldbank.org/servlet/WDS_IBank_Se rvlet?pcont $=$ details\&eid $=000009265 \_3961005173829$.

World Bank (1995). Rehabilitation Program: Implementation and Outlook, Report No. 13965. Washington, DC: World Bank, 27 February. Available at: http://www-wds.worldbank.org/ servlet/WDS_IBank_Servlet?pcont=details\&eid=000009265_3961007222725.

World Bank (1996). From Recovery to Sustained Development, Report No. 15593. Washington, DC: World Bank, 31 May. Available at: http://www-wds.worldbank.org/servlet/WDS_IBank_Se rvlet?pcont $=$ details\&eid=000009265_3961214134230.

World Bank (1997). Progress in Recovery and Reform, Report No. 16591. Washington, DC: World Bank, 2 June. Available at: http://www-wds.worldbank.org/servlet/WDS_IBank_Servlet?pco $\mathrm{nt}=$ details\&eid $=000009265 \_3971023103639$.

World Bank (1998). Assessing Aid: What Works, What Doesn't, and Why. Washington, DC: World Bank. Available at: http://www-wds.worldbank.org/servlet/WDS_IBank_Servlet?pcont=det ails\&eid=000094946_99030406212262. 
World Bank (1999). Cambodia: Poverty Assessment, Report 19858-KH. Washington, DC: World Bank, 22 November. Available at: http://www-wds.worldbank.org/servlet/WDSContentSer ver/WDSP/IB/1999/12/30/000094946_99122006055630/Rendered/PDF/multi_page.pdf.

World Bank (2000). Cambodia, Governance and Corruption Diagnostic: Evidence from Citizen, Enterprise and Public Official Surveys. Washington, DC: World Bank, May. Available at: http://www.worldbank.org/wbi/governance/pdf/guide_pdfs/06-survey_report.pdf.

World Bank (2004a). Cambodia at the Crossroads: Strengthening Accountability to Reduce Poverty, Report No. 30636-KH. Washington, DC: World Bank, 15 November. Available at: http:// siteresources.worldbank.org/INTCAMBODIA/Resources/1-report.pdf.

World Bank (2004b). Seizing the Global Opportunity: Investment Climate Assessment and Reform Strategy for Cambodia, Report No. 27925-KH. Washington, DC: World Bank, 12 August. Available at: http://siteresources.worldbank.org/INTCAMBODIA/Resources/Global-opportu nity.pdf.

World Bank (2005a). 'World Bank Group President James D. Wolfensohn Wraps Up Visit to Cambodia, Urges: "Seize the Opportunity", Press Release. Phnom Penh: World Bank, 11 February. Available at: http://web.worldbank.org/WBSITE/EXTERNAL/EXTABOUTUS/OR GANIZATION/EXTOFFICEPRESIDENT/EXTPASTPRESIDENTS/PRESIDENTEXTERNAL/ 0,,contentMDK:20352376 menuPK:219671 pagePK:159837 piPK:159808 theSitePK:227 $585,00 . \mathrm{html}$.

World Bank (2005b). World Development Indicators Online 2005. Washington, DC: World Bank.

World Bank (2006). Halving Poverty by 2015: Poverty Assessment 2006, Report No. 35213. Washington, DC: World Bank, 7 February. Available at: http://www-wds.worldbank.org/ servlet/WDSContentServer/WDSP/IB/2006/02/22/000012009_20060222102151/Rendered/PDF 352130RE V0pdf.pdf.

Yeng, V. (2006). 'Statement of Yeng Virak', Phnom Penh: Community Legal Education Center, 13 January. Available at: http://www.iri.org/asia/cambodia/pdfs/2006-01-17-Statement\%20of\% 20Yeng\%20Virak.pdf. 